\title{
Nanostructural Chemically Bonded Ca-Aluminate Based Bioceramics
}

\author{
Leif Hermansson \\ Doxa $A B$ \\ Sweden
}

\section{Introduction}

Biomaterials are based on a broad range of materials, such as organic polymers, metals and ceramics including both sintered and chemically bonded ceramics (silicates, aluminates, sulphates and phophates). The biomaterials can be made prior to use in the body in a conventional preparation of the material. The need for in situ in vivo formed implant materials makes the chemically bonded ceramics especially potential as biomaterials. These ceramics include room/body temperature formed biomaterials with excellent biocompatibility. Ca-aluminate as a biomaterial has been evaluated for over two decades with regard to general physical, mechanical and biocompatible properties. The Caaluminate based materials exhibit due to their unique curing/hardening characteristics and related microstructure a great potential within the biomaterial field. The presentation in this chapter aims at giving an overview of the use of Ca-aluminate (CA) as a biomaterial within odontology, orthopaedics and as a carrier material for drug delivery. The examination deals with aspects such as; the chemical composition selected, inert filler particles used, early properties during preparation and handling (working, setting, injection time, translucency, radio-opacity), and final long-term properties such as dimensional stability and mechanical properties (fracture toughness, compressive and flexural strength, hardness and Young's modulus). One specific topic deals with the sealing of the Ca-aluminate biomaterials to tissue - a key in the understanding of the mechanisms of nanostructural integration.

\section{Overview of properties of chemically bonded ceramics}

The Ca-aluminate bioceramics belong to the chemically bonded ceramics, which are usually presented or known as inorganic cements (Mangabhai, 1990). Three different cement systems - Calcium phosphates (CP), Calcium aluminates (CA) and Calcium silicates (CS) are discussed in some details in this section. Ceramic biomaterials are often based on phosphate-containing solubable glasses, and various calcium phosphate salts (Hench, 1998). These salts can be made to cure in vivo and are attractive as replacements for the natural calcium phosphates of mineralised tissues. The Ca-phosphate products are gaining ground in orthopaedics as resorbable bone substitutes. Biocements are often based on various calcium phosphate salts - sometimes in combination with Ca-sulphates (Nilsson, 2003). These salts can be made to cure in vivo and are attractive as replacements for the natural 
mineralised tissues. However, these products have low compression strength values - in the interval 10-40 $\mathrm{MPa}$ - and are therefore questioned as load bearing implants.

Materials based on Ca-aluminate (CA) and Ca-silicate (CS) with chemistry similar to that of Ca-phosphates $(\mathrm{CP})$ contribute to some additional features of interest with regard to dental and orthopaedic applications (Scriviner, 1988). The inherent difference in water uptake between the CA/CS-systems and $\mathrm{CP}$ gives benefits as:

- Higher mechanical strength.

- Possibility to add fillers, e.g. for improved radio opacity.

- Tuneable handling properties, e.g. rheology.

Materials based on Ca-aluminate and Ca-silicate thus contribute to some additional features of interest with regard to dental and orthopaedic applications. These features are related to the high amount of water involved in the curing process, the early and high mechanical strength obtained, and the biocompatibility profile including in situ reactions with phosphates ions of the body fluid. Compressive strength of cements based on Ca-silicate and Ca-aluminate is in the range $50-250 \mathrm{MPa}$ depending on the water to cement ratio. The mechanical properties tested for the three Ca-based cement systems are compiled in Table 1 (Kraft, 2002, Loof et al 2003, Engqvist et al 2006).

\begin{tabular}{|l|l|l|l|}
\hline Property profile after 7 days & $\begin{array}{l}\text { Ca-aluminate } \\
\text { based material }\end{array}$ & $\begin{array}{l}\text { Ca-silicate based } \\
\text { material }\end{array}$ & $\begin{array}{l}\text { Ca-phosphate } \\
\text { based material }\end{array}$ \\
\hline Compressive strength $(\mathrm{MPa})$ & $100-200$ & $100-150$ & $<100$ \\
\hline Flexural strength $(\mathrm{MPa})$ & $30-60$ & $30-40$ & $20-30$ \\
\hline Young's modulus $(\mathrm{GPa})$ & Approx. 15 & Approx. 11 & Approx. 3 \\
\hline
\end{tabular}

Table 1. Mechanical property profile of the Ca-aluminate, Ca-silicate and Ca-phosphate systems

The water content involved in the hydration of the different chemically bonded ceramics are presented in Table 2 .

\begin{tabular}{|c|c|c|c|c|}
\hline System & Typical phase(s) & Oxide formula & $\mathrm{Mol} \% \mathrm{H}_{2} \mathrm{O}$ & $\begin{array}{l}\text { Weight- } \% \text { in } \\
\text { hydrated product }\end{array}$ \\
\hline $\begin{array}{l}\text { Ca- } \\
\text { phosphate }\end{array}$ & Apatite & $10 \mathrm{CaO} 3 \mathrm{P}_{2} \mathrm{O}_{5} \mathrm{H}_{2} \mathrm{O}$ & 7 & Approx 5 \\
\hline Ca-aluminate & Katoite + gibbsite & $\begin{array}{l}3 \mathrm{CaO} \mathrm{Al}{ }_{2} \mathrm{O}_{3} 6 \mathrm{H}_{2} \mathrm{O} \\
+\mathrm{Al}_{2} \mathrm{O}_{3} 2 \mathrm{H}_{2} \mathrm{O}\end{array}$ & $>60$ & Approx 25 \\
\hline Ca-silicate & $\begin{array}{l}\text { Tobermorite }+ \\
\text { amorphous phases }\end{array}$ & $\begin{array}{l}5 \mathrm{CaO} 6 \mathrm{SiO}_{2} 5 \mathrm{H}_{2} \mathrm{O} \\
+\mathrm{Ca}, \mathrm{Si}) \mathrm{H}_{2} \mathrm{O}\end{array}$ & $>30$ & Approx 20 \\
\hline
\end{tabular}

Table 2 . The three chemically bonded ceramic systems most used for biomaterials

\subsection{Materials and basic function}

\subsubsection{Main chemistry}

The injectability and handling features of the chemically bonded ceramics is mainly caused by the added water as the reacting phase with the powdered cements. This reaction is an acid-base reaction where water acts as a weak acid and the cement powder as a base. Several cement phases exist in the $\mathrm{CaO}-\mathrm{Al}_{2} \mathrm{O}_{3}$ (CA) and in the $\mathrm{CaO}-\mathrm{SiO}_{2}$ (CS) systems, see Figure 1 , but only a few are suitable as injectable materials. For one of the most attractive phases - 


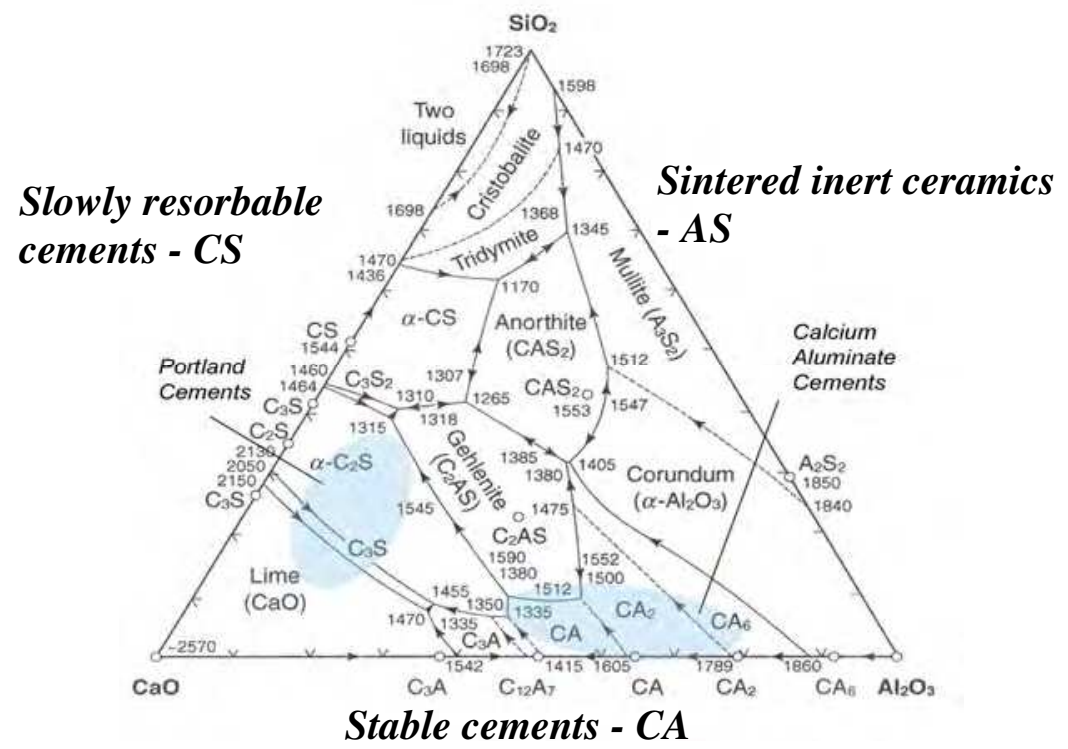

Fig. 1. The phase diagram of the high-strength bioceramic cements (Muan and Osbourne, 1965)

the mono Ca-aluminate, $\mathrm{CaOxAl}_{2} \mathrm{O}_{3}$ - the reaction at above $30{ }^{\circ} \mathrm{C}$ is described using cement chemical abbreviation as (Mangabhai, 1990);

$$
3 \mathrm{CA}+12 \mathrm{H} \rightarrow \mathrm{C}_{3} \mathrm{AH}_{6}+2 \mathrm{AH}_{3}
$$

Or

$$
3\left(\mathrm{CaAl}_{2} \mathrm{O}_{4}\right)+12 \mathrm{H}_{2} \mathrm{O} \rightarrow \mathrm{Ca}_{3}\left(\mathrm{Al}(\mathrm{OH})_{4}\right)_{2}(\mathrm{OH})_{4}+4 \mathrm{Al}(\mathrm{OH})_{3}
$$

This example demonstrates 1 ) the phases obtained, $\mathrm{C}_{3} \mathrm{AH}_{6}$ (katoite) and $\mathrm{AH}_{3}$ (gibbsite), and 2 ) the amount water consumed in the reaction. The technological importance of this is that all the water needed for paste like consistency or injectability can be consumed in the formation of solid phases yielding products with low porosity, one of the requirements for high strength. As can be seen in Eq. (1) three $\mathrm{CaAl}_{2} \mathrm{O}_{4}$ units consume twelve water molecules during hardening. This can be compared with the hardening of Calcium Phosphate Cement (CPC) where practically no extra water is consumed. In the case of CPC, the reaction liquid is only used as a vehicle for the reaction to take place. In both cases the hardening and formation of a solid body are driven by the precipitation of small hydrates, nano-size crystals of katoite and gibbsite for CA, and apatite or brushite for CPC. The amount required water is as high as $28 \%$ for CA. The water content of apatite, $\mathrm{Ca}_{5}\left(\mathrm{PO}_{4}\right)_{3} \mathrm{OH}$, or $10 \mathrm{CaO} \times 3 \mathrm{P}_{2} \mathrm{O}_{5} \mathrm{H}_{2} \mathrm{O}\left(\mathrm{C}_{10} \mathrm{P}_{3} \mathrm{H}\right)$ is $2 \%$. The $\mathrm{CPC}$-system may contain some additional Casulphate which can pick up some extra water. An additional $30 \%$ Gypsum, $\mathrm{CaSO}_{4} \frac{1}{2} \mathrm{H}_{2} \mathrm{O}$ to the CPC-system yields approximately a total water content of $6 \%$.

The rate of the hydration is controlled by 1) the cement phase, 2) the particle size of the cement, 3) the hydration temperature and 4) processing agents including especially accelerators. Typical powder composition data for CA-cements as biomaterials are shown in 
Table 3. Zirconia or high-density glasses are added for achievement of increased strength and increased radio-opacity. The glasses are used preferentially in dental applications where translucency is an additional desired feature. The high radiopacity of zirconia or other heavy-element containing phases means that the physician during the injection can follow the paste penetration in bone tissue without risking any possible leakage of the material into the surrounding tissue.

\begin{tabular}{|l|l|l|l|l|}
\hline Compound & Formula & Function & $\begin{array}{l}\text { Amount } \\
(\mathrm{wt}-\%)\end{array}$ & $\begin{array}{l}\text { Mean particle } \\
\text { size }\end{array}$ \\
\hline Ca-aluminate & $\mathrm{CaOxAl}_{2} \mathrm{O}_{3}$ & Cement binder & $50-70$ & $<5 \mu \mathrm{m}$ \\
\hline $\begin{array}{l}\text { Zirconium } \\
\text { dioxide }\end{array}$ & $\mathrm{ZrO}_{2}$ & Radiopacier & $20-40$ & $<1 \mu \mathrm{m}$ \\
\hline$\mu$-Silica & $\mathrm{SiO}_{2}$ & $\begin{array}{l}\text { Expansion and } \\
\text { viscosity controller }\end{array}$ & $<10$ & $<50 \mathrm{~nm}$ \\
\hline
\end{tabular}

Table 3. Typical composition of an injectable biomaterial cement powder.

Typical processing agents are accelerators/retarders, dispersants, viscosity agents to control reaction rate, temperature and the cohesiveness, and in general the rheology. Examples are lithium chloride, polycarboxylate polymers and cellulose, as well as glass poly-alkeonates. For the CS-system Ca-chloride at high concentrations is normally used as an accelerator. For cements as injectable biomaterials, the reaction rate must be controlled with respect to working time, setting time, curing time and the maximum temperature during hydration. Typical data are presented in Table 4. The cement reactions are all exothermic and the temperature raise is controlled by the specific cement phase selected, and the hydration rate and the amount of material injected. For dental application the temperature raise is limited to a few ${ }^{\circ} \mathrm{C}$ above $37{ }^{\circ} \mathrm{C}$. For orthopaedic applications where larger amounts $\left(2-10 \mathrm{~cm}^{3}\right)$ are used the temperature raise is more pronounced but lower than that of the conventional PMMA-based materials (Lewis, 2006).

\begin{tabular}{|l|l|l|l|}
\hline System & $\begin{array}{l}\text { Working time at 23 } \\
{ }^{\circ} \mathrm{C}, \text { min }\end{array}$ & $\begin{array}{l}\text { Setting time at 37 } \mathrm{oC}, \\
\text { min }\end{array}$ & $\begin{array}{l}\text { Max reaction temperature, } \\
{ }^{\circ} \mathrm{C}\end{array}$ \\
\hline Ca-aluminate & Approx. 5 & $8-12$ & $\begin{array}{l}<60, \\
\text { (for dental applications }< \\
40)\end{array}$ \\
\hline Ca-silicate & Approx. 10 & $15-18$ & $<45$ \\
\hline Ca-phosphate & 5 & $10-12$ & $<40$ \\
\hline PMMA & $5-10$ & 11 & $<90$ \\
\hline
\end{tabular}

Table 4. Typical working and setting times and maximum reaction temperature of the systems discussed.

The on-going precipitation of hydrates and the reduction of the amount of liquid phase result in the formation of a material skeleton. This repeating reaction is fast at the beginning, resulting in a hardened product within 4-20 minutes depending on intended application. Strength corresponding to load carrying capacity is reached after approximately one hour. 
However, the final strength and in the case of dental applications the translucency (Engqvist et al 2004), are reached after approximately a few days maturing.

It should be noted that for CBC materials, irrespective of chemistry (CA, CS or CPC), the final porosity cannot be zero. When the hydrates precipitate there is a contraction of approximately $10 \%$. The porosity is in the nanometer range and its exact amount is difficult to determine, but $<10 \%$ of the filled space (the original liquid-phase volume) is estimated to be pores. However, this internal shrinkage related to hydration and precipitation yield no total shrinkage of the bulk material. In contrast, a limited expansion close to zero, may be induced (Kraft 2002). The porosity lowers the mechanical strength (although being in the nanometer range) but also enables liquids to diffuse into, or even through, the hardened CBC materials. This is an important feature when release of loaded drugs is a complementary aspect of the injectable biomaterial.

\section{Ca-aluminate - general description and property profile}

Ca-aluminates comprise double oxides of $\mathrm{CaO}$ and $\mathrm{Al}_{2} \mathrm{O}_{3}$. Several intermediate phases exist and these are - using the cement chemistry abbreviation system - $\mathrm{C}_{3} \mathrm{~A}, \mathrm{C}_{12} \mathrm{~A}_{7}, \mathrm{CA}, \mathrm{CA}_{2}$ and $\mathrm{CA}_{6}$, where $\mathrm{C}=\mathrm{CaO}$ and $\mathrm{A}=\mathrm{Al}_{2} \mathrm{O}_{3}$. See Fig. 1 above. Table 5 presents typical property data.

\begin{tabular}{|l|l|l|}
\hline Property & Typical value & Interval $^{*}$ \\
\hline Compression strength, MPa & 150 & $60-270$ \\
\hline Young's modulus, GPa & 15 & $10-20$ \\
\hline Thermal conductivity, W/mK & 0.8 & $0.7-0.9$ \\
\hline Thermal expansion, ppm/K & 9.5 & $9-10$ \\
\hline Flexural strength, MPa & 50 & $20-80$ \\
\hline Fracture toughness, MPam ${ }^{1 / 2}$ & 0.5 & $0.3-0.8$ \\
\hline $\begin{array}{l}\text { Corrosion resistance, water jet impinging, reduction in } \\
\text { mm }\end{array}$ & $<0.01$ & - \\
\hline Radio-opacity, mm & 1.5 & $1.4-2.5$ \\
\hline Process temperature, ${ }^{\circ} \mathrm{C}$ & $>30$ & $30-70$ \\
\hline Working time, min & 3 & $<4$ \\
\hline Setting time, min & 5 & $4-7$ \\
\hline Curing time, min & 20 & $10-60$ \\
\hline Porosity after final hydration, $\%$ & 15 & $5-60$ \\
\hline
\end{tabular}

The interval is primarily related to the $\mathrm{c} / \mathrm{w}$ ratio used, and the highest values are achieved with $\mathrm{c} / \mathrm{w}$ ratio close to that of complete hydration with no excess of water

Table 5. Mean property data of dental Ca-aluminate based materials (Kraft 2002, Lööf 2008, Lööf et al 2004,2005, Hermansson et al 2008)

Due to reduced porosity based on the huge water uptake ability, the Ca-aluminate material exhibit the highest strength among the chemically bonded ceramics. The inherent flexural strength is above $100 \mathrm{MP}$ based on measurement of the fracture toughness, which is about $0.7-0.8 \mathrm{MPam}^{1 / 2}$. The actual flexural strength is controlled by external defects introduced during handling and injection of the material. The thermal and electrical properties of Caaluminate based materials are close to those of hard tissue, the reason being that Caaluminate hydrates chemically belong to the same group as Ca-phosphates, the hard tissue 
of bone. Another important property related to Ca-aluminate materials is the possibility to control the dimensional change during hardening. In contrast to the shrinkage behaviour of many polymer-based biomaterials, the Ca-aluminates exhibit a small expansion, 0.1-0.3 linear-\% (Kraft 2002).

\subsection{Biocompatibility including bioactivity}

\section{Definitions used}

The terms biocompatibility and bioactivity are used in different ways by different categories of scientists. Below are presented the definitions used in this paper, mainly agreeing with the definitions discussed in (Williams, 1987) Biocompatibility: "The ability of a material to perform with an appropriate host response in a specific application".

Bioactivity (bioactive material): "A material which has been designed to induce specific biological activity". Another definition according to (Cao and Hench,1996) "A bioactive material is one that elicits a specific response at the interface of the material which results in the formation of a bond between the tissues and the material".

Thus a material cannot in itself be classified as biocompatible without being related to the specific application, for which it is intended. Bioactivity from a materials viewpoint is frequently divided into in vitro and in vivo bioactivity. The in vitro bioactivity of a material is however only an indication that it might be bioactive in a specific in vivo application. Another aspect of bioactivity is that this term can be adequate only when the biomaterial is in contact with a cellular tissue. However, often a material is claimed to be bioactive if it also reacts with body liquids forming an apatite-phase. In vitro bioactivity is tested in phosphate buffer systems similar to that of saliva or body liquid, and apatite formation is the claimed sign of bioactivity. A further aspect of bioactivity and also biocompatibility deals with the different curing times and temperatures at which the observation (testing) is performed. This is important to issues such as initial $\mathrm{pH}$-development, cohesiveness and initial strength. Finally the biocompatibility and bioactivity can only be confirmed in clinical situations, with the actual implant/biomaterial in the designed amount or content and shape. This is especially important for injectable biomaterials which are formed (hydrated) and cured in vivo, and for implants where movements, even micro-movement, can influence the outcome.

\section{Standards and methods}

Relating to the definition aspects above, the acceptance of a biomaterial is a crucial issue, and to some extent the question has been solved by relating to the following toxicological endpoints indicating biocompatibility as referred in the harmonized standard ISO 10993:2003, which comprises the following sections:

Cytotoxicity (ISO10993-5), Sensitization (ISO10993-10), Irritation/Intracutaneous reactivity (ISO10993-10), Systemic toxicity (ISO10993-11), Sub-acute, sub-chronic and chronic toxicity (ISO10993-11), Genotoxicity (ISO10993-3), Implantation (ISO10993-6), Carcinogenicity (ISO10993-3) and Hemocompatibility (ISO10993-4).

This will be the main guideline when presenting the status of the biocompatibility of the CASPH-system, but was complemented by corrosion testing, elementary analysis, $\mathrm{pH}$ change and additional cytotoxicity testing.

The corrosion resistance test - using a water jet impinging technique - was conducted according to EN 29917:1994/ISO 9917:1991, where removal of material is expressed as a height reduction using $0.1 \mathrm{M}$ lactic acid as solution, $\mathrm{pH} 2.7$. The duration time of the test is 
$24 \mathrm{~h}$. The test starts after $24 \mathrm{~h}$ hydration. The test probe accuracy was $0.01 \mathrm{~mm}$. Values below $0.05 \mathrm{~mm}$ per $24 \mathrm{~h}$ solution impinging are judged as acid resistant.

Determination of $\mathrm{Ca}$ and $\mathrm{Al}$ in the solution during the hydration process of the Caaluminate based material was performed using atomic absorption spectrometry (Liu et al 2002). Standard solutions of different concentrations of $\mathrm{Ca}$ and $\mathrm{Al}$ were prepared according to the manual. Samples were prepared with a size of $10 \mathrm{~mm} \times 2 \mathrm{~mm}$ height using a wet-press method, corresponding to a surface area of $224 \mathrm{~mm}^{2}$. The test pieces were placed in plastic bottles in inorganic saliva solution of $\mathrm{pH}$. The amount of liquid was $10 \mathrm{ml}$ in each bottle. The temperature selected was $37{ }^{\circ} \mathrm{C}$. The inorganic saliva solution contained calcium chloride, magnesium chloride, sodium chloride, a phosphate buffer, hydro-carbonate and citric acid. The Ca-content in the saliva solution corresponded to $68 \mathrm{ppm} .1 \mathrm{ml}$ solution was removed at 1, 7 and 28 days for analyses, and saliva was exchanged at 1, 7 and 28 days after every measurement. For the 28 days test additional samples were also taken $1 \mathrm{~h}$ after new solution was added.

Measurement of $\mathrm{pH}$ development during hydration of the material was conducted using a standard pH-meter. Samples were prepared according to the procedure for atomic absorption described above. The $\mathrm{pH}$-testing was conducted in two separate ways. First the samples were immersed in saliva solution $(\mathrm{pH}=7)$ at $37{ }^{\circ} \mathrm{C}$, and $\mathrm{pH}$ was measured continually over the whole experiment period (Test 1). $1 \mathrm{ml}$ solution was removed at 1, 7, 14 and 28 days for $\mathrm{pH}$ measurement. The second type of measurement comprised immersion in $10 \mathrm{ml}$ saliva solution at $37{ }^{\circ} \mathrm{C}$, where the saliva was exchanged at $1,7,14$ and 28 days. $\mathrm{pH}$ was measured at the time of observation and also after one hour in new saliva (data within brackets), Test 2 .

Specimens at different setting stages were subjected to cytotoxicity testing by using primary cultures of human oral fibroblasts. A tissue culture insert retaining tested materials was assembled into a 12-well plate above the fibroblast monolayers. The cytotoxicity was determined by MTT reduction assay after various curing times. Specimens were set and hydrated at $37{ }^{\circ} \mathrm{C}$ for different periods of time, i.e. $0,5,30,60 \mathrm{~min}, 24 \mathrm{~h}$ and 1 week and were then placed on tissue culture netwell for a cytotoxicity test. Both acute ( 1 and $24 \mathrm{~h}$ ) and long term (1 week) in vitro toxicity tests were conducted with MTT assay.

\subsubsection{Biocompatibility including bioactivity of Ca-aluminate bioceramics}

\section{Biocompatibility evaluation}

Summarized below are the results from several biocompatibility and bioactivity studies (Engqvist 2004, 2005, Faris 2006) where Ca-aluminate is used as a biomaterial in orthopaedic and dental applications. In vitro bioactivity studies show apatite formation on the surface of the Ca-aluminate materials exposed to phosphate buffer solution, an example shown in Figure 2 below.

\section{Corrosion resistance}

No height reduction at all was observed for two tested Ca-aluminate materials. Thus, according to the acid corrosion test, Ca-aluminate materials are judged as stable materials. The total absence of material loss, measured as height reduction in the acid corrosion test, is related to the general basic nature of the material, with possibility of neutralization of the acid in the contact zone - especially in the earlier stage of the hydration process. 


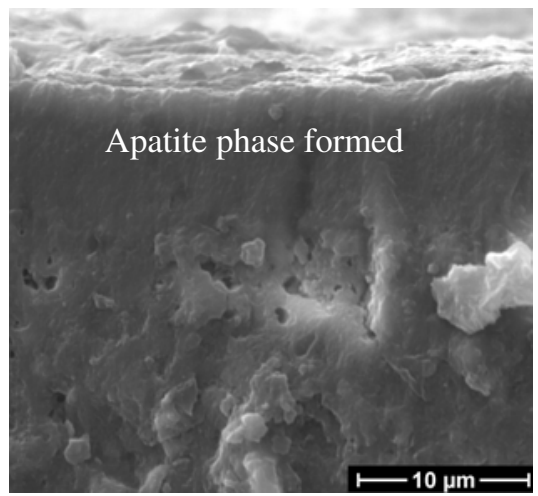

Fig. 2. Cross section of the apatite-containing surface layer formed, SEM (Engqvist et al, 2004)

\section{Ion release measured by atomic absorption spectrometry}

The results of $\mathrm{Ca}$ and $\mathrm{Al}$ determination in the solution during the hydration process of the Ca-aluminate based material are presented in Table 6.

\begin{tabular}{|l|l|l|l|ll|}
\hline Ion tested & $1 \mathrm{~h}, \mathrm{ppm}$ & $24 \mathrm{hrs}, \mathrm{ppm}$ & 7 days, $\mathrm{ppm}$ & 28 days, $\mathrm{ppm}$ \\
\hline $\mathrm{Ca}$ & 66 & 64 & 44 & $50 \quad(70)$ \\
\hline $\mathrm{Al}$ & 11.4 & 9.3 & 9.6 & $8.6 \quad(1.2)$ \\
\hline
\end{tabular}

Table 6. Ca and $\mathrm{Al}$ dissolution during hardening of the Ca-aluminate material, (The $1 \mathrm{~h}$ testing at 28 days within brackets)

The release of metal ions in water was below $5 \times 10^{-2} \mathrm{ppm} /\left(\mathrm{mm}^{2}\right.$ material $)$ for aluminium and below 30x10-2 $\mathrm{ppm} /\left(\mathrm{mm}^{2}\right.$ material $)$ for calcium, whereas somewhat higher aluminium content was measured in artificial saliva. The ion concentrations detected are generally not time-dependent during hydration. After the initial hydration time the ion concentration (molar) is determined by the solubility product of the phases formed (katoite $=5 \times 10^{-26}$ and gibbsite $\left.=3 \times 10^{-24}\right)$. Since the concentration of $\mathrm{Ca}$ in saliva is higher than what is obtained in the non-physiological aqueous solution (distilled water), it can be assumed that the filling material releases very limited amounts of $\mathrm{Ca}$ or $\mathrm{Al}$ once the material has hardened. The presence of $\mathrm{Ca}$ in saliva will decrease the solubility tendency of the calcium-aluminatehydrate phases.

Based on a search in the literature, the FAO/WHO Joint Expert Committee on Food Additives (JECFA) has provided a provisional figure for tolerable weekly aluminium intake of $7 \mathrm{mg} / \mathrm{kg}$ body weight. This corresponds to $1 \mathrm{mg} / \mathrm{kg} /$ day. The daily intake of aluminium via digestion/food is approximately $5 \mathrm{mg}$ per day. For calcium the NIH Consensus Development Conference on Optimal Calcium Intake recommended an intake in the range $800 \mathrm{mg} /$ day for young children to $1000-1500 \mathrm{mg} /$ day for adults depending on gender and age. For many people there is a need to supply additional calcium in order to stay healthy. The ion concentrations measured and the amounts of $\mathrm{Ca}$ and $\mathrm{Al}$ released are far below the concentrations of the elements produced from food intake and should therefore not pose any safety concerns at all. 


\section{Change in $\mathrm{pH}$ during hydration}

The results of the measurement of $\mathrm{pH}$ development during hydration of the Ca-aluminate based are shown in Table 7. The initial in vitro-pH is 10.5 in saliva. After 1 week, $\mathrm{pH}$ after $1 \mathrm{~h}$ dissolution time in saliva is approx. 8 .

\begin{tabular}{|c|c|c|c|c|c|c|}
\hline Test No. & At start & $1 \mathrm{~h}$ & $24 \mathrm{hrs}$ & 7 days & 14 days & 28 days \\
\hline 1 & 10.5 & 10.3 & 10.7 & 10.3 & 9.9 & 9.8 \\
\hline 2 & 10.5 & 10.2 & $10.2(7.7)$ & $9.9(7.8)$ & $9.5(8.1)$ & $9.2(8.1)$ \\
\hline
\end{tabular}

Table 7. Change of $\mathrm{pH}$ during initial hydration of Ca-aluminate based materials

The $\mathrm{pH}$ is high during the early stage of the hydration, but decreases with time and approaches neutrality. The reason for the high $\mathrm{pH}$ in the beginning is the general basic character of the material and the formation of $\mathrm{OH}^{-}$during the hydration process. In the clinical situation saliva is produced in a dynamic way, creating an environment capable of buffering surrounding solution to neutrality. In the clinical studies performed so far no adverse reactions have been reported from a possible elevated $\mathrm{pH}$ during the early part of the hydration.

When Ca-aluminate material is combined with glass ionomer system the pH-system becomes initially acidic. However after $10 \mathrm{~min}$ the $\mathrm{pH}$ is above neutral, but will not exceed pH 9 (Jefferies et al 2009).

\section{Cytotoxicity testing}

The in vitro MTT reduction test of the experimental Ca-aluminate dental filling material in human oral fibroblast culture showed no obvious cytotoxicity. The average level of MTT reduction of the experimental dental filling material was close to $100 \%$ of the control values. The maximal variation (SD) was less than $30 \%$. Different curing times of the test material did not seem to affect the cytotoxicity test results although one week curing produced the most stable testing results both in the short and long term tests. After a week the material can be considered as fully cured, i.e. stable.

Morphological changes were not observed in any of the test groups at different MTT reduction testing points. As shown in Figure 3, the cell culture was typically fibroblastic with a slender and elongated form in both the control group and the group exposed to the examined material. In the exposed picture B even some precipitated hydrates are seen.

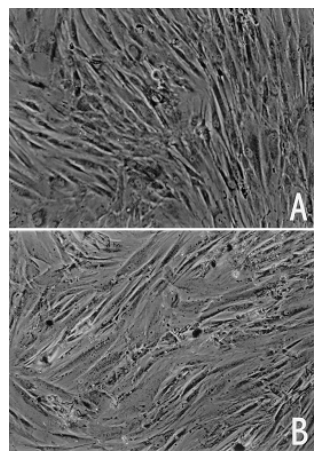

Fig. 3. Morphological observation of human oral fibroblasts on an experimental Caaluminate based material. A: Normal control. B: After exposure to the experimental filling material for one week (Liu et al 2002). 
The standard for cellular biocompatibility in in vitro testing has been stated in the International Organization for Standardization (ISO) standards documents. The standard allows for the contact testing of solid dental materials for cytotoxicity with cell lines. Due to several disadvantages of direct contact testing, indirect testing methods have been developed and compared to the direct testing assays (Tang et al 2002). Introduction of a standard cell culture device, i.e. cell culture insert or transwell, provided an opportunity for such cytotoxicity screening of dental materials with indirect contact between material specimens and cell culture monolayer. It is believed that such a testing system more closely mimics the in vivo exposure pattern by providing the test of the material in both its solid and dissolved phases at the same time. It has been shown that this testing system has produced the most stable results as compared to other testing systems, such as direct contact test. In a complementary cytotoxicity test using the pulp derived cell response, the experimental CAmaterial showed no sign of toxicity (Schmalz 2002).

\section{Harmonized standard ISO 10993:2003}

Further cytotoxicity and other biocompatibility aspects are summarised according to the outline in the harmonized standard ISO 10993:2003. An experimental orthopaedic Caaluminate-based material was the test material. This material is judged as mildly cytotoxic during the initial curing, and as non-cytotoxic as cured material. See Table below.

\begin{tabular}{|l|c|c|}
\hline Type of test & Method & Cytotoxicity (scale 0-4 or 100-0\% \\
\hline During curing, undiluted & ISO 10993-5, § 8.2 & 2 (mild) \\
\hline During curing, diluted & ISO 10993-5, § 8.2 & $0-1$ (none-slight) \\
\hline During curing & XTT-test & $60 \%$ (slight) \\
\hline During curing, diluted & XTT-test & $>70 \%$ (none) \\
\hline Cured, undiluted & ISO 10993-5, $§ 8.2$ & 0 (none) \\
\hline Cured, diluted $\rightarrow$ diluted & XTT-test & $>70 \%$ (none) \\
\hline
\end{tabular}

Table 8. Cytotoxicity testing of an orthopaedic Ca-aluminate based material

A sensitization test (ISO 10993-10), Guinea Pig Maximization Test was performed with the orthopaedic Ca-aluminate material during curing. No sensitizing potential was obtained. Additional irritation and delayed hypersensitivity testing according to ISO 10993-10:2002 was conducted with both polar and non-polar extract from cured material, and the results showed no discrepancies after intracutaneous injections in the rabbit compared to the blank injections. The acute systemic toxicity study according to ISO 10993-11 was performed with both polar and non-polar extracts from cured Ca-aluminate material (Xeraspine), and the results showed no signs of acute systemic toxicity. Sub-acute, sub-chronic and/or chronic toxicity studies according to ISO 10993-11 were not conducted explicitly, since data from the two implantation studies in rabbit (see below) were judged to support that no long term toxicity is expressed. From the implantation studies histopathological organ and tissue data is available, and no adverse effects were reported.

Additionally, in an in vivo genotoxicity assay, the mice micronucleus test of bone marrow was used. The extract (The experimental Ca-aluminate material during curing and cured material) was administered intraperitoneally twice. The results showed no clastogenic effect. Three in vivo implantation studies based on ISO 10993-6 have been performed. Two studies in rabbit (femur) and one in sheep (vertebrae). In vivo implantation studies are judged as the most relevant studies for documentation of safety of a product. In the rabbit implantation 
studies Ca-aluminate material was compared to the PMMA-material CMW 1, and in the sheep study Ca-aluminate material was compared to the PMMA-material Vertebroplastic, and to the Bis-GMA material Cortoss ${ }^{\mathrm{TM}}$. The results are summarized in Table 9.

\begin{tabular}{|c|c|c|l|}
\hline Implantation studies & Species & Reference material & \multicolumn{1}{|c|}{ Result } \\
\hline 6-week femur & Rabbit & CMW-1 & $\begin{array}{l}\text { Minimal inflammation, } \\
\text { very few inflammatory } \\
\text { cells were present in bone, } \\
\text { bone marrow and adipose } \\
\text { tissues. }\end{array}$ \\
\hline 6 (12)-month femur & Rabbit & CMW-1 & No Al- accumulation \\
\hline 12-week vertebrae & Sheep & $\begin{array}{c}\text { Vertebroplastic } \\
\text { Cortoss }\end{array}$ & $\begin{array}{l}\text { No inflammation, } \\
\text { no Al-accumulation }\end{array}$ \\
\hline
\end{tabular}

Table 9. Implantation studies in femur rabbit, and in vertebrae sheep, details in (Hermansson et al 2008)

The 6 months femur study in rabbits included a 12 months subgroup. The amount of aluminium in blood and selected organs was analysed. The main target organs of the animals (kidney, lung, liver) were histopathologically investigated. Granulomatous inflammation in the cavity, pigmented macrophages and new bone formation were the treatment-related observations at 6- and12-months examination. No difference between Caaluminate material and PMMA was detected. There were no signs of aluminium accumulation in the analysed tissues.

In the 12-week study, the histopathology of vertebrae obtained one week after surgery showed the most severe inflammatory reaction to the surgery in the sham operated vertebrae. The bone marrow in the vertebrae filled with Ca-aluminate was not reported to be infiltrated by any inflammatory cells. In vertebrae obtained 12 weeks after surgery no inflammatory reactions were reported, and no obvious differences were observed in the pathological reactions to the surgery (sham) or the filler materials. Overview of the histological contact zone to the Ca-aluminate based material is shown in Figure 4.

The analysis of serum samples showed low concentrations of aluminum in comparison to what is normal in humans. Since the concentration of aluminum did not increase after surgery and in some instances was lower after surgery than in the 0-samples, one may regard these concentrations as within the normal variation.

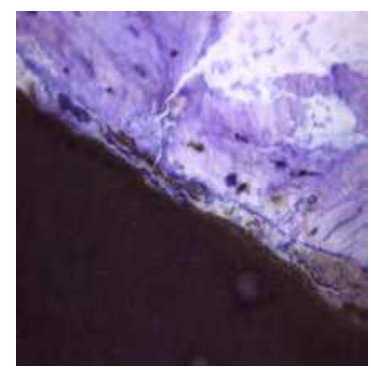

Fig. 4. Histology image of an experimental Ca-aluminate material (black) in close contact with sheep vertebral bone. 
Repeated haemocompatibility studies have been performed to evaluate possible reactions in whole human blood as a result of contact with Ca-aluminate materials (Axen et al 2004). Test items were an experimental Ca-aluminate based material and Xeraspine, Vertebroplastic and Norian (Calcium Phosphate Cement, Synthes Inc). A Chandler loop model was used in which circulating human blood was in contact with the test materials for up to 4 hours. For comparison, loops free from test materials were used. Platelet count (PLT), thrombin-antithrombin (TAT) complex, complement factors C3a and C5b-9 (TCC), and TNF-a were assayed. The degree of haemolysis was assessed by the Drabkin method. Norian (a calcium phosphate based material) invariably induced extensive clotting already after 60 minutes, verified macroscopically and also by significantly reduced PLT in comparison to the Control loops, whereas there was no significant reduction in PLT in the loops with Ca-alumiante material or Vertebroplastic, respectively, neither at 60 nor at 240 minutes. The Ca-aluminate material did not induce haemolysis to a greater extent than any of the other materials tested. TCC was activated to a certain degree by the biomaterial, comparable to what is commonly observed for artificial materials. TNF-a generation, indicative of activation of white blood cells, was not enhanced by either Vertobroplastic or the Ca-aluminate material.

Based on all above mentioned data and generated toxicity data, it is considered that there is no reason to expect that the Ca-aluminate biomaterials when used in accordance with the intended clinical use will create any adverse effects. The Ca-aluminate based materials fulfill the requirements of the harmonized standard ISO 10993:2003.

3.1.1.1 Complementary reactions of Ca-aluminate in presence of body liquid.

Complementary reactions occur when the Ca-aluminate is in contact with tissue containing body liquid. Several mechanisms have been identified, which control how the Ca-aluminate material is integrated onto tissue. These mechanisms affect the integration differently depending on what type of tissue the biomaterial is in contact with, and in what state (unhydrated or hydrated) the CA is introduced. These mechanisms are summarized as follows and described in more details elsewhere (Hermansson, 2009);

Mechanism 1:

Main reaction, the hydration step of CAC (Eq. 1 above)

Mechanism 2:

Apatite formation in presence of phosphate ions in the biomaterial

Mechanism 3:

Apatite formation in the contact zone in presence of body liquid

Mechanism 4:

Mechanism 5:

Transformation of hydrated Ca-aluminate into apatite and gibbsite

Mechanism 6:

Biological induced integration and ingrowth, i.e. bone formation at the contact zone

Point-welding due to mass increase when in contact with body liquid.

When phosphate ions or water soluble phosphate compounds are present in the biomaterial (powder or liquid) an apatite formation occurs according to the reaction

$$
5 \mathrm{Ca}^{2+}+3 \mathrm{PO}_{4}^{3-}+\mathrm{OH}^{-} \rightarrow \mathrm{Ca}_{5}\left(\mathrm{PO}_{4}\right)_{3} \mathrm{OH}
$$

This complementary reaction to the main reaction occurs due to the presence of Ca-ions and a basic $(\mathrm{OH})$ environment created by the Ca-aluminate material. The solubility product of apatite is very small $\left[\mathrm{Ks}=10^{-58}\right]$, so apatite is easily precipitated. Body liquid contains among others the following ions $\mathrm{HPO}_{4}{ }^{2-}$ and $\mathrm{H}_{2} \mathrm{PO}_{4}{ }^{-}$. In contact with the Ca-aluminate 
system and water during setting and hydration, the presence of Ca-ions and hydroxyl ions, the hydrogen phosphate ions are neutralised according to

$$
\mathrm{HPO}_{4}^{2-}+\mathrm{H}_{2} \mathrm{PO}_{4}^{-}+\mathrm{OH}^{-} \rightarrow \mathrm{PO}_{4}^{2-}+\mathrm{H}_{2} \mathrm{O}
$$

whereafter the apatite-formation reaction occurs

$$
5 \mathrm{Ca}^{2+}+3 \mathrm{PO}_{4}^{3-}+\mathrm{OH}^{-} \rightarrow \mathrm{Ca}_{5}\left(\mathrm{PO}_{4}\right)_{3} \mathrm{OH}
$$

This reaction occurs upon the biomaterial surface/periphery towards tissue. The apatite is precipitated as nano-size crystals (Hermansson et al, 2006). See figure 5.

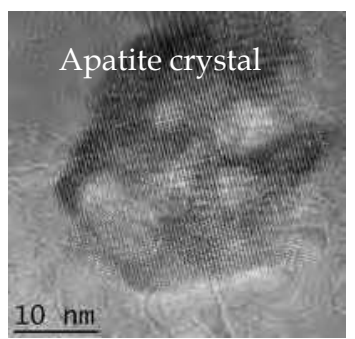

Fig. 5. Nano-size apatite formation in the the contact zone to hard tissue

Katoite is formed as a main phase, and is kept as katoite in the bulk material according to the mechanism 1 above. However, in long-time contact with body liquid containing phosphate ions the katoite is transformed at the interface tobody tissue into the at neutral $\mathrm{pH}$ even more stable apatite and gibbsite phases according to

$$
\begin{gathered}
\mathrm{Ca}_{3} \cdot\left(\mathrm{Al}(\mathrm{OH})_{4}\right)_{2} \cdot(\mathrm{OH})_{4}+2 \mathrm{Ca}^{2+}+\mathrm{HPO}_{4}^{2-}+2 \mathrm{H}_{2} \mathrm{PO}_{4}^{-} \rightarrow \\
\mathrm{Ca}_{5} \cdot\left(\mathrm{PO}_{4}\right)_{3} \cdot(\mathrm{OH})+2 \mathrm{Al}(\mathrm{OH})_{3}+5 \mathrm{H}_{2} \mathrm{O}
\end{gathered}
$$

When apatite is formed at the interface according to any of the reaction mechanisms 2-4 above, at the periphery of the bulk biomaterial, the biological integration may start. Bone ingrowth towards the apatite allows the new bone structure to come in integrated contact with the biomaterial. This is an established fact for apatite interfaces. For the CA-system the ingrowth is discussed below, 4.4. The transition from tissue to the biomaterial is smooth and intricate.

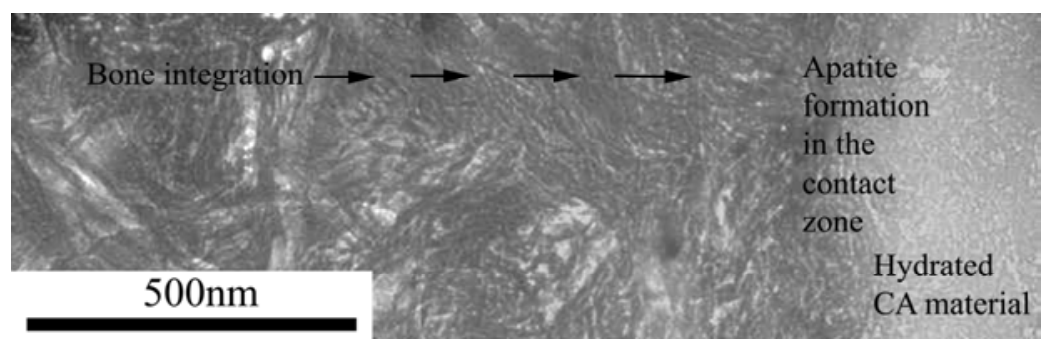

Fig. 6. Integration of CA in tissue - a model using albino adult New Zealand White rabbits (Hermansson et al, 2008). 
The actual contact zone developed depends on a combination of the above discussed mechanisms and the tissue. The latter varies from a cellular-free high content apatite tissue in the case of a dental enamel, via dentine to a bone structure with cellular and body liquid contact. Also the material can be in contact with other implant materials as dental crowns, dental screws or coatings on implants. In the tables 10 and 11 are summarized in which applications and specific tissues the demonstrated mechanisms are predominant.

\begin{tabular}{|l|c|c|c|c|c|c|}
\hline Tissue & Mech 1 & Mech 2 & Mech 3 & Mech 4 & Mech 5 & Mech 6 \\
\hline Enamel & $\mathrm{x}$ & $\mathrm{x}$ & & & & \\
\hline Dentine & $\mathrm{x}$ & $\mathrm{x}$ & $\mathrm{X}$ & $\mathrm{x}$ & $(\mathrm{x})$ & \\
\hline Bone & $\mathrm{x}$ & $\mathrm{x}$ & $\mathrm{X}$ & $\mathrm{x}$ & $\mathrm{x}$ & $\mathrm{x}$ \\
\hline
\end{tabular}

Table 10. Type of tissue and possible mechanisms.

\begin{tabular}{|l|c|c|c|c|c|c|}
\hline Application & Mech 1 & Mech 2 & Mech 3 & Mech 4 & Mech 5 & Mech 6 \\
\hline Cementation & $\mathrm{x}$ & $\mathrm{x}$ & $\mathrm{x}$ & $\mathrm{x}$ & $\mathrm{x}$ & \\
$\begin{array}{l}\text { a. towards tissue } \\
\mathrm{b} \text {. towards implant }\end{array}$ & $\mathrm{x}$ & $\mathrm{x})$ & & & & \\
\hline $\begin{array}{l}\text { Dental fillings } \\
\text { a. towards enamel }\end{array}$ & $\mathrm{x}$ & $\mathrm{x}$ & & & & \\
$\mathrm{b}$. towards dentine & $\mathrm{x}$ & $\mathrm{x}$ & $\mathrm{x}$ & $\mathrm{x}$ & $(\mathrm{x})$ & \\
\hline $\begin{array}{l}\text { Endo fillings } \\
\text { a. orthograde }\end{array}$ & $\mathrm{x}$ & $\mathrm{x}$ & $\mathrm{x}$ & $\mathrm{x}$ & $\mathrm{x}$ & \\
b. retrograde incl bone & $\mathrm{x}$ & $\mathrm{x}$ & & & & \\
\hline $\begin{array}{l}\text { Coatings and augmentation } \\
\text { towards implant } \\
\text { gap filling }\end{array}$ & $\mathrm{x}$ & $\mathrm{x}$ & $\mathrm{x}$ & $\mathrm{x}$ & $\mathrm{x}$ & $\mathrm{x}$ \\
\hline
\end{tabular}

Table 11. Applications and possible mechanisms.

\section{Nanostructure and nano-porosity used in certain applications}

The nanostructure including nanoporosity developed in the Ca-aluminate biomaterial system when near complete hydration occurs, yields some unique properties related to how bacteriostatic and antibacterial properties may develop in the biomaterial. The nanoporosity can also be used to control release of drugs incorporated the biomaterial. The background to this is that even if the total porosity is low, all porosity is open, thus allowing transport of molecules in the nanoporosity channels. The nanostructure used in thin film coatings will also be touched upon.

\section{Antibacterial aspects}

The surprising finding in studies recently performed (Doxa patent application 2010) shows that the bacteriostatic and antibacterial properties of the Ca-aluminate biomaterial are not primarily related to $\mathrm{pH}$ or specific ions and ion concentration or reducing agents, but to the hydration procedure and the microstructure obtained. This also to some extent is an answer why highly biocompatible and even bioactive biomaterials can combine apparently contradictory features such as biocompatibility, bioactivity and apatite formation and environmental friendliness with bacteriostatic and antibacterial properties. 
The bacteriostatic and antibacterial properties are primarily related to the development of the nanostructure and the nano-size porosity during hydration of the Ca-aluminate system. The initial low $\mathrm{pH}(<8)$ of the system in the case of the presence of a polycarboxylic acid for cross-linking, is such not a hindrance for the antibacterial properties. The requirements of the microstructure of Ca-aluminate and/or Ca-silicate based biomaterials to achieve antibacterial properties are related to the general nanostructure obtained; A nanoparticle/crystal size of hydrates in the interval $15-40 \mathrm{~nm}$, a nanoporosity size of $1-4 \mathrm{~nm}$ and the number of pores per square micrometer of at least 500, preferably $>1000$.

The above mentioned requirements will guarantee that the nanostructure will be free of large pores meaning no escape of bacteria within the original liquid, paste or dental void, during the hydration. The nanocrystals will participate on all walls, within the liquid, and on all inert particles and on bacteria within the original volume. The formation of nanocrystals will continue to all the void is filled. The bacteria will be totally encapsulated and will be chemically dissolved. Also the number of nanopores will be extremely which will have the possibility of catching and fasten bacteria to the hydrate surface - an analogue to how certain peptides may function as antibacterial material due to a structure with nanosize hole within the structure.

\section{Materials and biomaterials application}

Alternative dental materials and implant materials based on bioceramics are found within all the classical ceramic families: traditional ceramics, special ceramics, glasses, glassceramics, coatings and chemically bonded ceramics (CBC) (Ravaglioli and Krajewski, 1992). The CBC-group, also known as inorganic cements, is based on materials in the system CaO$\mathrm{Al}_{2} \mathrm{O}_{3}-\mathrm{P}_{2} \mathrm{O}_{5}-\mathrm{SiO}_{2}$, where phosphates, aluminates, and silicates are found. Depending on in vivo chemical and biological stability, the $\mathrm{CBC}$ biomaterials can be divided into three groups: stable, slowly resorbable and resorbable. The choice for dental and stable materials is the Ca-aluminate based materials (Hermansson et al 2008). Slowly resorbable materials are found within Ca-silicates and Ca-phosphates, and fast resorbing materials among Casulphates and some Ca-phosphates. The stable biomaterials are suitable for dental applications, long-term load-bearing implants, and osteoporosis-related applications. For trauma and treatment of younger patients, the preferred biomaterial is the slowly resorbable materials, which can be replaced by new bone tissue (Nilsson, 2002). In this section are summarised some of the possible new applications using the strong chemically bonded ceramics based on Ca-aluminate. The presentation is devided in three application areas; dental, orthopaedics and drug delivery.

The following product areas have been identified based on experimental material data, preclinical studies, pilot studies and on-going clinical studies (Jefferies et al, 2009). The application areas are; Dental cement, endodontic products (orthograde and retrograde), sealants, restoratives, and pastes for augmentation and dental implant coatings. For lowviscosity and early hardening of the CA, a complementary glass ionomer can preferrably be used. Clinical use of the materials is foreseen within the next coming years. The use of CA within odontology is based on the following features; early/rapid anchoring, high strength, long-term stability, no shrinkage, combined bonding and bulk material, biocompatibility and in situ apatite formation ability (nanocrystals formed in the contact zone between material and tissue). 


\subsection{Dental applications}

The existing dental materials are mainly based on amalgam, resin composites or glass ionomers. Amalgam, originating from the Tang dynasty in China, was introduced in the early $19^{\text {th }}$ century as the first commercial dental material. It is anchored in the tooth cavity by undercuts in the bottom of the cavity to provide mechanical retention of the metal. Although it has excellent mechanical characteristics it is falling out of favor in most dental markets because of health and environmental concerns. One exception is the US in which amalgam still has a redlatively large market share.

The second generation material is the resin composites, first introduced in the late 1950s. These are attached to the tooth using powerful bonding agents that glue them to the tooth structure. After technical problems over several decades, these materials today have developed to a level where they work quite well and provide excellent aesthetic results. Despite the improvements, resin composites have some drawbacks related to shrinkage, extra bonding, irritant components, a risk of post-operative sensitivity, and technique sensitivity in that they require dry field treatment in the inherently moist oral cavity. The key problem, due to shrinkage or possible degradation of the material and the bonding, is the margin between the filler material and tooth, which often fails over time leading to invasion of bacteria and secondary caries. Secondary caries is a leading cause of restorative failure and one of the biggest challenges in dentistry today. As a significant number of dental restorations today are replacement of old, failed tooth fillings, it is clear that tackling this problem is a major market need (Mjör, 2000). Secondary caries occurs not only after filling procedures but also following other restorative procedures such as the cementation of crowns and bridges.

Glass ionomers were first introduced in 1972 and today are an established category for certain restorations and cementations. Their main weakness is the relatively low strength and low resistance to abrasion and wear. Various developments have tried to address this, and in the early 1990s resin-modified ionomers were introduced. They have significantly higher flexural and tensile strength and lower modulus of elasticity and are therefore more fracture-resistant. However, in addition to the problems of resin composites highlighted above, wear resistance and strength properties are still inferior to those of the resin composites.

The nature of the mechanisms utilized by Ca-aluminate materials (especially Mechanism 1 above) when integrating and adhering to tooth tissue and other materials makes these materials compatible with a range of other dental materials, including resin composite, metal, porcelain, zirconia, glass ionomers and gutta-percha. This expands the range of indications for Ca-aluminate based products from not only those involving tooth tissue, e.g. cavity restorations, but also to a range of other indications that involve both tooth tissue and other dental materials. Examples include dental cementation, base and liner and core buildup and endodontic sealer / filler materials, which involve contact with materials such as porcelain, oxides and polymers and metals, and coatings on dental implants such as titanium or zirconia-based materials.

The use of the Ca-alumiante materials may be a first step towards a paradigm shift for dental applications. The features are summarized below.

Nanostructural integration

- $\quad$ Reduced risk of secondary caries and restoration failure

- Excellent biocompatibility 
- $\quad$ Reduced/no post-operative sensitivity, environmentally friendly and no allergy

- Optimized consistency and setting properties for the intended application

- Reliable clinical handling performance

- Hydrophilic acid-base system with no extra bonding or no dry field precaution

- $\quad$ Fast and easy clinical handling, no pre-treatment of tooth necessary

- Excellent retentive and mechanical properties, no degradation of properties over time

- Durable tooth-material restoration interface (longevity).

Below are presented in more details the state-of-the-art for different possible applications of Ca-aluminate based materials.

\subsubsection{Dental cement}

Long-term success after cementation of indirect restorations depends on retention as well as maintenance of the integrity of the marginal seal. Sealing properties of great importance deal with microleakage resistance, the retention developed between the dental cement and the environment, compressive strength and acid resistance. Data presented below support the Ca-aluminate-system as highly relevant for dental cement materials. Integration with tooth tissue is a powerful feature and the foundation of the Ca-aluminate technology platform. Secondary caries occurs not only after filling procedures but also after other restorative procedures such as the cementation of crowns and bridges. The consequence of the difference in the mechanism of action between Ca-aluminate products and conventional products is illustrated by the study presented in details in (Pameijer et al , 2008, 2009), illustrated in Figure 2 below. It shows that the micro leakage, measured by dye penetration after thermo cycling, of a leading dental cement (Ketac Cem $\left.{ }^{\circledR}, 3 \mathrm{M}\right)$ was significantly higher, both before and after thermo cycling compared to Ceramir C\&B, a Ca-aluminate based product recently approved by FDA. This has also recently been verified using techniques for studying actual bacterial leakage. The above described nanostructural precipitation upon tissue walls, biomaterials and within the original Ca-aluminate paste is the main reason for this, in addition to a high acid corrosion resistance.

General properties of the CAPH-system used as dental cement have been presented (Pameijer et al, 2008), see Fig. 7 and Table 12 below. General features of all the dental cement classes available are presented as a summary in Table 13 below.

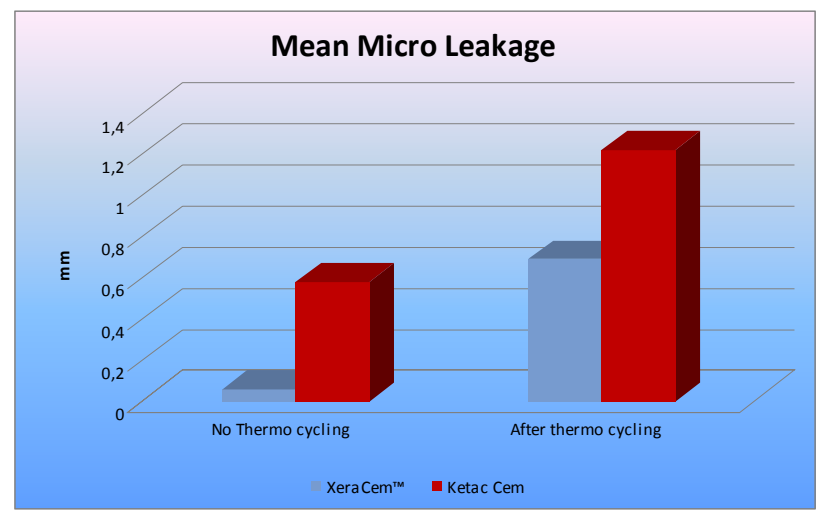

Fig. 7. Micro leakage leakage of a Ca-aluminate based material (blue) and Ketac Cem (red). 


\begin{tabular}{|c|c|c|c|c|}
\hline Material & $\begin{array}{c}\text { Net setting } \\
\text { time, min }\end{array}$ & $\begin{array}{c}\text { Film thickness, } \\
\mu \mathrm{m}\end{array}$ & $\begin{array}{c}\text { Compressive } \\
\text { strength, MPa }\end{array}$ & $\begin{array}{c}\text { Crown } \\
\text { retention, } \\
\text { Kg/Force }\end{array}$ \\
\hline $\begin{array}{c}\text { Ca-aluminate } \\
\text { based }\end{array}$ & 4.8 & 15 & 196 (at 30days) & 38.6 \\
\hline Ketac Cem & - & 19 & - & 26.6 \\
\hline RelyX-Unicem & - & - & 157 & 39.4 \\
\hline
\end{tabular}

Table 12. Selected properties, Test methods according to SO 9917-1

\begin{tabular}{|c|c|c|c|c|c|c|}
\hline $\begin{array}{l}\text { Material } \\
\text { aspects }\end{array}$ & $\begin{array}{c}\text { Glass } \\
\text { Ionomer } \\
(\mathrm{GI})\end{array}$ & $\begin{array}{c}\text { Resin- } \\
\text { modified GI }\end{array}$ & $\begin{array}{c}\text { Resin } \\
\text { (bonded) }\end{array}$ & $\begin{array}{c}\text { Self-adhesive } \\
\text { Resin }\end{array}$ & $\begin{array}{c}\mathrm{Zn-} \\
\text { phosphate } \\
\text { cement }\end{array}$ & $\begin{array}{l}\text { Ceramir } \\
\text { C\&B }\end{array}$ \\
\hline $\begin{array}{l}\text { 1. Type } \\
\text { of material }\end{array}$ & Polymer & Monomer & Monomer & Monomer & $\begin{array}{c}\text { Inorganic } \\
\text { material }\end{array}$ & $\begin{array}{l}\text { Ceramic- } \\
\text { polymer }\end{array}$ \\
\hline $\begin{array}{l}\text { 2. Hardening } \\
\text { mechanism }\end{array}$ & $\begin{array}{l}\text { Cross- } \\
\text { linking }\end{array}$ & $\begin{array}{c}\text { Poly- } \\
\text { merisation }\end{array}$ & $\begin{array}{c}\text { Poly- } \\
\text { merisation }\end{array}$ & $\begin{array}{c}\text { Poly- } \\
\text { merisation }\end{array}$ & $\begin{array}{l}\text { Acid-base } \\
\text { reaction }\end{array}$ & $\begin{array}{l}\text { Acid-base }+ \\
\text { cross-linking }\end{array}$ \\
\hline 3. $\mathrm{pH}$ & Acidic & Acidic & $\begin{array}{c}\text { Acidic } \\
\text { /neutral }\end{array}$ & $\begin{array}{c}\text { Acidic } \\
\text { / neutral }\end{array}$ & Acidic & $\begin{array}{l}\text { Acidic } \\
\text { / basic } \\
\end{array}$ \\
\hline $\begin{array}{l}\text { 4. Geo- } \\
\text { metrical } \\
\text { stability }\end{array}$ & $\begin{array}{c}\text { Non- } \\
\text { shrinking }\end{array}$ & $\begin{array}{c}\text { Non- } \\
\text { shrinking }\end{array}$ & Shrinks & Shrinks & $\begin{array}{c}\text { Non- } \\
\text { shrinking }\end{array}$ & $\begin{array}{c}\text { Non- } \\
\text { shrinking }\end{array}$ \\
\hline $\begin{array}{l}\text { 5. Stability } \\
\text { over time }\end{array}$ & Degrades & Degrades & Degrades & Degrades & Degrades & Stable \\
\hline $\begin{array}{l}\text { 6. Extra } \\
\text { treatment }\end{array}$ & - & - & $\begin{array}{c}\text { Etching and } \\
\text { bonding }\end{array}$ & - & - & - \\
\hline $\begin{array}{l}\text { 7. Hydro- } \\
\text { philic / } \\
\text { phobic } \\
\end{array}$ & $\begin{array}{c}\text { Hydro- } \\
\text { philic }\end{array}$ & Hydrophilic & Hydrophobic & $\begin{array}{c}\text { Initially } \\
\text { hydrophilic, } \\
\text { Hydrophobic }\end{array}$ & Hydrophilic & Hydro-philic \\
\hline $\begin{array}{l}\text { 8. Integration } \\
\text { mechanism }\end{array}$ & \begin{tabular}{|c|} 
Micro- \\
mechani- \\
cal \\
retention, \\
Chemical \\
bonding
\end{tabular} & \begin{tabular}{|c|} 
Micro- \\
mechanical \\
retention / \\
Chemical \\
bonding / \\
Adhesion
\end{tabular} & $\begin{array}{l}\text { Adhesion / } \\
\text { Micro- } \\
\text { mechanical } \\
\text { retention }\end{array}$ & $\begin{array}{l}\text { Adhesion / } \\
\text { Micro- } \\
\text { mechanical } \\
\text { retention }\end{array}$ & $\begin{array}{c}\text { Micro- } \\
\text { mechanical } \\
\text { retention }\end{array}$ & $\begin{array}{c}\text { Nano- } \\
\text { structural } \\
\text { integration }\end{array}$ \\
\hline $\begin{array}{l}\text { 9. General } \\
\text { behaviour }\end{array}$ & \begin{tabular}{|l|} 
Irritant \\
\end{tabular} & Allergenic & Allergenic & Allergenic & $\begin{array}{c}\text { Non- } \\
\text { allergenic }\end{array}$ & $\begin{array}{c}\text { Non- } \\
\text { allergenic }\end{array}$ \\
\hline $\begin{array}{l}\text { 10. Biocom- } \\
\text { patibility }\end{array}$ & Good & OK & $\mathrm{OK}$ & OK & Good & Good \\
\hline 11. Bioactivty & No & No & No & No & No & Bioactive \\
\hline $\begin{array}{l}\text { 12. Sealing } \\
\text { quality }\end{array}$ & OK & OK & $\begin{array}{l}\text { Good but } \\
\text { operation } \\
\text { sensitive }\end{array}$ & OK & Acceptable & Excellent \\
\hline
\end{tabular}

Table 13. Overview of dental luting cements (Hermansson et al, 2010)

Material aspects 4-12 in Table 13 are also relevant for all other Ca-aluminate based dental applications. 
A clinical 2-year study comprising 35 cemented crowns was conducted at Kornberg School of Dentistry, Temple University, and follow-up data and feedback from participating dentists were excellent with no failures at all reported (Jefferies et al 2009).

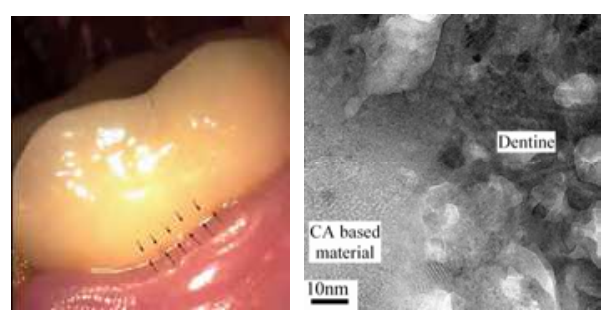

Fig. 8. Cemented ceramic crown (left), and HRTEM of the nanostructure of Ca-aluminate hydrates, hydrates formed in the interval 10-30 nm(right), bar $=10 \mathrm{~nm}$ (Hermansson et al, 2010)

\subsubsection{Endodontics}

In a review of the biocompatibility of dental materials used in contemporary endodontic therapy (Haumann and Love, 2003) amalgam was compared with gutta-percha, zinc oxideeugenol (ZOE), polymers, glass ionomer cements (GICs), composite resins and mineral trioxide aggregate (MTA). A review (Niederman, 2003) of clinical trials of in vivo retrograde obturation materials summarized the findings. GIC's appeared to have the same clinical success as amalgam, and orthograde filling with gutta-percha and sealer was more effective than amalgam retrograde filling. Retrograde fillings with composite and Gluma, EBA cement or gold leaf were more effective than amalgam retrograde fillings. However, none of the clinical trials reviewed in included MTA. In a 12 week microleakage study, the MTA performance was questioned compared to that of both amalgam and a composite (Alamo et al, 1999).

The Ca-aluminate-based material discussed in this paper belongs to the same material group as MTA, the chemically bonded ceramics. MTA is a calcium silicate (CS) based cement having bismuth oxide as filler material for improved radio-opacity, whereas the Caaluminate material consists of Ca-aluminate phases $\mathrm{CA}$ and $\mathrm{CA}_{2}$ with zirconia as filler material. MTA is claimed to prevent microleakage, to be biocompatible, to regenerate original tissues when placed in contact with the dental pulp or periradicular tissues, and to be antibacterial. The product profile of MTA describes the material as a water-based product, which makes moisture contamination a non-issue (Dentsply 2003). The CA-cement materials are more acid resistant than the CS-based materials, and in general show higher mechanical strength than the CS materials. A two-year and a five-year retrospective clinical study of Ca-aluminate based material have been conducted (Pameijer et al, 2004, Kraft et al, 2009). The study involved patients with diagnosis of either chronic per apical osteitis, chronic per apical destruction, or trauma. Surgery microscope was used in all cases. For orthograde therapy the material was mixed with solvent into appropriate consistency and put into a syringe, injected and condensed with coarse gutta-percha points. Machine burs were employed for root canal resection. For the retrograde root fillings, the conventional surgery procedure was performed. The apex was detected with surgery microscope and rinsed and prepared with an ultrasonic device. Crushed water-filled CA-tablets were then inserted and condensed with dental instruments. The patients' teeth were examined with X- 
ray, and three questions regarding subjective symptoms were put to patients: 1 . Have you had any persistent symptoms? 2. Do you know which tooth was treated? 3. Can you feel any symptoms at the tooth apex?

In 13 of the 17 treated patients the diagnosis was chronic perapical osteitis (c p o). These were treated with retrograde root filling (rf) therapy. Three patients suffered from trauma or chronic perapical destruction, and these patients were treated with orthograde therapy. Out of 17 patients ( 22 teeth) treated, 16 patients ( 21 teeth) were examined with follow-up x-ray after treatment and also after two years or more. The additional patient was asked about symptoms. The results of both the clinical examination and the subjective symptoms were graded into different groups related to the success of the therapy. The results of the 2-year and the 5-year study are shown in Table 14.

\begin{tabular}{|c|cc|cc|cc|cc|}
\hline & \multicolumn{2}{|c|}{$\begin{array}{c}\text { 1 Complete } \\
\text { healing }\end{array}$} & \multicolumn{2}{c|}{$\begin{array}{c}\text { 2 Incomplete } \\
\text { healing }\end{array}$} & 3 Uncertain & \multicolumn{2}{c|}{4 Failure } \\
\hline & 2-year & 5-year & 2-year & 5-year & 2 year & 5-year & 2-year & 5-year \\
\hline Nos. of teeth & 18 & 14 & 3 & 2 & 0 & 0 & 1 & 0 \\
\hline Percentage & 82 & 87 & 14 & 13 & 0 & 0 & 4 & 0 \\
\hline
\end{tabular}

Table 14. Summary of the results (Score 1 and 2 considered successful, score 3 and 4 failure)

Figures 9-10 show examples of the X-ray examination of orthograde and retrograde treatments.

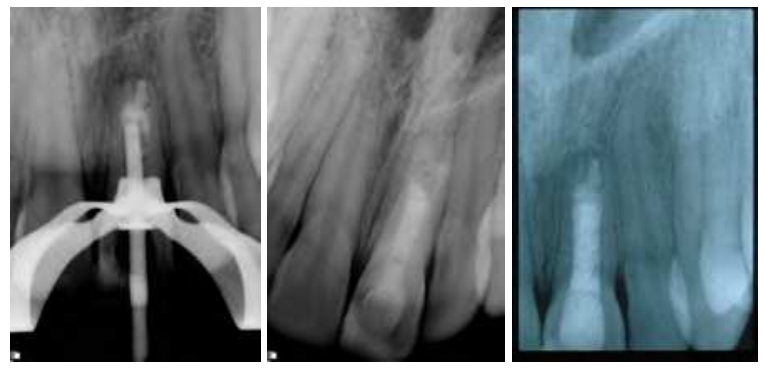

Fig. 9. Tooth 21 (patient14) a) condensing with a Gutta-percha pointer, b) just after treatment and c) at two year control
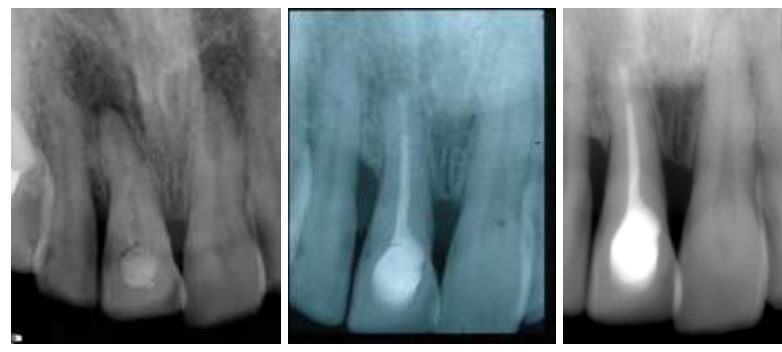

Fig. 10. Tooth 21 (patient 9) at treatment (left) and at two year control (middle) and at 5 year control (right)

In summary 21 out of 22 treated teeth have acceptable results being either symptom free or judged healed after clinical examination. The single failure can probably not be attributed to 
the material, but rather to the difficulty of treating and sealing a multi-channelled tooth. The use of CA's as root canal sealers is indirectly supported in "Introduction to Dental Materials" by van Noort (van Noort, 1994), where the following materials characteristics are looked for; biocompatible, dimensionally stable, antibacterial and bioactive. The results in this study can be interpreted as a success in meeting these materials requirements.

Already in the 1970s, Calcium aluminate (CA) was suggested as a biomaterial and tested in vivo. Hentrich et al (Hentricht et al, 1994) compared CA with alumina and zirconia in an evaluation of how the different ceramics influenced the rate of new bone formation in femurs of rhesus monkeys. Hamner et al (Hamnar and Gruelich, 1972) presented a study in which 22 CA roots were implanted into fresh natural tooth extraction sites in 10 baboons for periods ranging from 2 weeks to 10 months. In both studies CA successfully met the criteria for tissue adherence and host acceptance.

\subsubsection{Dental filling materials}

An important feature of the hydration mechanisms of the Ca-aluminate based materials is the nanostructural integration with and the high shear strength developed towards dental tissue. This makes both undercut (retention) technique and bonding techniques redundant. The Ca-aluminate approach to dental filling technique is new. With this technique, the chemical reactions cause integration when the bioceramic material is placed in the oral cavity at body temperature and in a moist treatment field. Figure 11 shows a TEM (transmission electron microscopy) illustration of the interface between the CA-based material and dentine. This establishes a durable seal between bioceramic and tooth. Whereas amalgam attaches to the tooth by mechanical retention and resin-based materials attach by adhesion, using bonding agents, etchants, light-curing or other complementary techniques, the CA-materials integrate with the tooth without any of these, delivering a quicker, simpler and more robust solution.

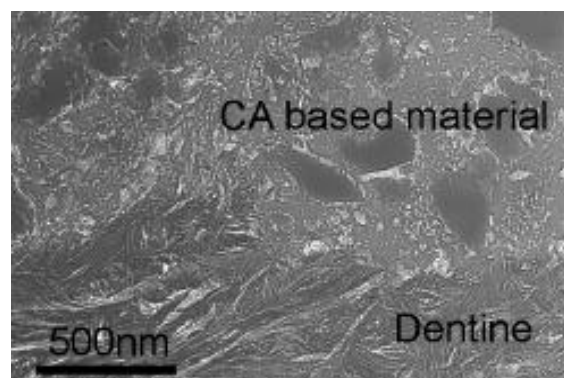

Fig. 11. Nanostructural integration of CAPH-material with dentine (gray particles in the biomaterial are glass particles)

The general aspects of Ca-aluminate based materials have been presented in two $\mathrm{Ph} \mathrm{D}$ Thesis-publications. Important aspects of Ca-aluminate materials as dental filling materials are dealt with, such as dimensional stability, acid corrosion and wear resistance, and biocompatibility and mechanical properties (Kraft 2002, Lööf et al 2003).

\subsubsection{Coatings on dental implant and augmentation}

For successful implantation of implants in bone tissue, early stabilisation is of great importance (Ellingsen and Lyngstaadas, 2003). This includes both orthopaedic and dental 
implants. Even small gaps may lead to relative micro-motions between implant and the tissue, which increases the risk of implant loosening over time due to formation of zones of fibrous tissues at the implant-tissue interface. Early loading of implants is of particular interest for dental implants (Vercaigne et al, 1998). The use of surface coatings technology is today an established method to reduce the problem with poor interfacial stability for implants. With coatings technology, structural characteristics of the implant (e.g. strength, ductility, low weight or machinability) may be combined with surface properties promoting tissue integration. There are several established coating deposition techniques, e.g. physical vapour deposition (sputtering) and thermal spraying techniques. Coatings based on calcium phosphates are the most used ones.

This section deals with coatings deposited with established methods, with the aim of improving particularly the early stage anchoring of metal implants to bone tissue by exploring in vivo hydration of coatings or pastes based on chemically curing ceramics. The study focuses on calcium aluminate in the form of coatings and paste. Results are presented from an implantation study with flame-sprayed coating on titanium implants and uncoated implants augmented with a calcium aluminate paste in the hind legs of rabbits. Implants were applied with the paste composed of a mixture of $\mathrm{CaO} \cdot \mathrm{Al}_{2} \mathrm{O}_{3}$ and $\mathrm{CaO} \cdot 2 \mathrm{Al}_{2} \mathrm{O}_{3}$. The paste was applied manually as a thin layer on the threaded part of the implant just before implantation. The uncoated and coated implants were sterilised with hot dry air at $180{ }^{\circ} \mathrm{C}$ for $2 \mathrm{hrs}$. Female albino adult New Zealand White rabbits with a body weight around $2.5 \mathrm{~kg}$ were used. Each animal received four implants, two in each hind leg. Implants were placed in the distal femoral metaphysis as well as in the proximal tibial metaphysis. Surgery followed standard procedure. The implants were screwed into predrilled and threaded cavities. Necropsy took place after 24 hrs, 2 and 6 weeks (Axen et al, 2005).

No negative effects of the implants on the general welfare of the animals were observed. The healing progressed in a normal and favourable way. As for the removal torque recordings, all calcium aluminate coatings types provided an improved implant anchoring to bone tissue after in vivo hydration, as compared to that of the pure metal implants. Implants on the tibia and femur side of the knee gave similar removal torques. Table 15 provides average values from both tibia and femur sides.

\begin{tabular}{|l|l|l|l|l|l|l|}
\hline Implant type & $24 \mathrm{hrs}$ & $(\mathrm{n})$ & 2 weeks & $(\mathrm{n})$ & 6 weeks & $(\mathrm{n})$ \\
\hline Flame spraying & 7.0 & $(8)$ & 7.0 & $(8)$ & 25 & $(6)$ \\
\hline Paste augmentation & 6.6 & $(8)$ & 15 & $(6)$ & 13 & $(4)$ \\
\hline Rf-PVD & 12 & $(4)$ & - & - & 10 & $(4)$ \\
\hline Uncoated reference & 3.8 & $(8)$ & 5.7 & $(6)$ & 14 & $(4)$ \\
\hline
\end{tabular}

Table 15. Removal torque (Ncm) for dental implants in rabbit hind legs (tibia and femur).

$24 \mathrm{hrs}$ after implantation, calcium aluminate in-between the implant and tissue increased the removal torque to about double that of the uncoated reference implants, independently of means of application (coatings or paste). This is considered to be attributable to the pointwelding according to integration mechanism 6 above. Two weeks after implantation, implants combined with paste augmentation provide the highest removal torque; flame sprayed coatings also improve the torque relative to the uncoated system. Six weeks after implantation, all systems are relatively similar (considering the uncertainty due to scatter and statistics), apart from the sprayed system which shows significantly higher values. 


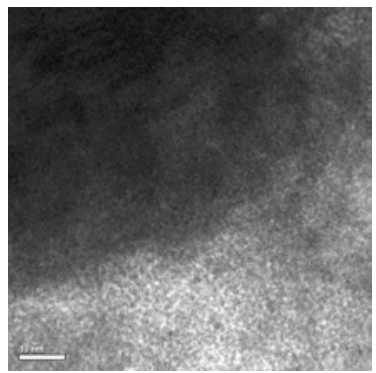

Fig. 12. High-resolution TEM of Ti - CA-paste interface, nano-mechanical integration, bar = $10 \mathrm{~nm}$.

\subsection{Orthopaedic applications}

Within orthopedics the following areas for Ca-aluminate based materials have been identified; percutaneous vertebroplasty (PVP) and kyphoplasty (KVP), trauma and general augmentation.

The benefits of the injectable ceramic biomaterials based on CA related to orthopaedic applications are

During the surgical procedure (Engqvist et al, 2005, Lööf et al 2008)

- High radiopacity allows for superior visibility of the cement during and increases the probability to detect potential leakages during injection (See Figs. 13-14 below)
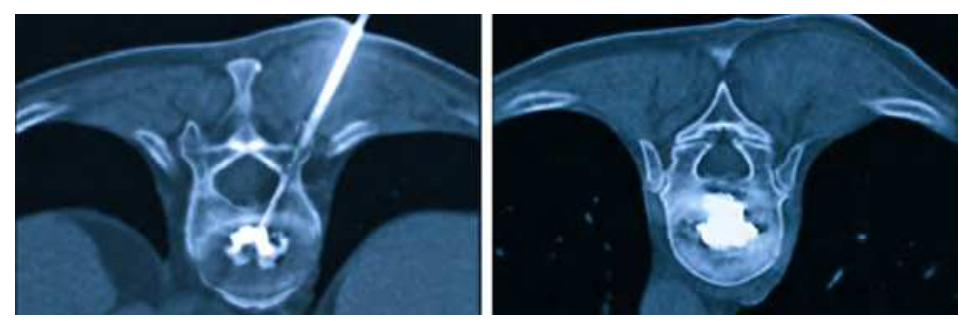

Fig. 13. Percutaneous vertebroplasty using a CA-material.

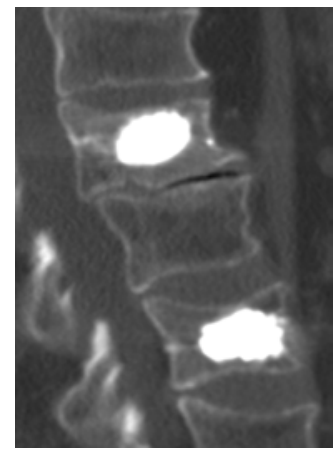

Fig. 14. Vertebral compression factures, restored by CA-material. 
- High and linearly increasing viscosity reduces the risk of leakage and gives a

- predictable handling.

- High cohesiveness optimizes the cement's filling pattern in the vertebra.

- No toxic or smelling fumes

And after the procedure (Jarmar et al, 2008, Engqvist et al 2006)

- Mechanical strength

- Biocompatibility including integration

- $\quad$ Long-term stability i.e. non-resorbable systems.

\subsection{Drug carrier for drug delivery}

General aspects of ceramics for use in drug delivery of drugs are presented by Ravaglioli et al and by Lasserre and Bajpaj (Ravaglioli et al, 2000, Lasserre and Bajpaj, 1998). A short description of carrier materials for drug delivery using chemically bonded ceramics, especially Ca-aluminate and/or Ca-silicate systems are given below. The CBC carrier material based on CA and CS structures exhibit some attractive features. The manufacturing procedure at low temperatures, where no or limited degradation of the medicaments occur, and the microstructure developed with open porosity as nano-sized channels as described above, are the basic features that open up a possibility for controlled release of medical agents. The precursor powder cures as a result of hydration reactions, between a ceramic oxide powder, primarily Ca-silicates and/or Ca-aluminates, and water. Through the hydration, new phases of hydrates are formed, which to a great part establish the microstructures needed to control the release of drugs incorporated in the injectable precursor material. An injectable material is formed into a paste by mixing it with a waterbased hydration liquid, which is then ready to be injected. Directly after the injection, the paste starts to develop the final microstructure. The water-based liquid may also comprise viscosity-controlling additives. These may be loaded with the drug before preparation of the final injectable paste. A couple of unique reaction conditions related to the production of materials yields materials with a variety of possible microstructures with porosities from the nanoscale to the microscale. variety of possible microstructures with porosities from the nanoscale to the microscale. 3) pore size and pore channel size, and 4) combination of different porosity structures (Hermansson, 2010). Porosity generated during the hydration of the Ca-aluminates and Ca-silicates is open porosity due to the reaction mechanism, and can be in the interval of 5-60 vol.- $\%$. The average pore channel size (i.e. the diameter of the pores formed between the particles of the hydrated material) may be $1-10 \mathrm{~nm}$. The crystal size of the reacted hydrates is in the interval $10-50 \mathrm{~nm}$. This was established by BETmeasurements, where the specific surface area of dried hydrated CA was determined to be in the interval $400-500 \mathrm{~m}^{2}$, corresponding to a particle size of approximately $25 \mathrm{~nm}$, and by HRTEM [7], Fig. 1 below. When short hydration time and/or low amount of water, or moisture at relative humidity $>70 \%$, are used, additional porosity is achieved with pore sizes in the interval 0.1-1 micrometer due to incomplete reaction. The different pore sizes obtained can be utilized for controlled release of drugs, when the Ca-aluminate implant material also works as a carrier of medicaments.

\section{Drug loading and controlled release of drugs}

The following properties are of significance with regard to the carrier for controlling the drug release; Type of ceramic precursor for producing the chemically bonded ceramic, grain size distribution of the precursor powder particles and general microstructure of the 
material, he microstructure of the additional particles for drug incorporation, and additives to ensure complementary porosity.

The loading of the drug can be performed in several ways. The drug may be included, either partially or fully, in the powder or in the hydration liquid. Time and temperature for hydration are selected with regard to the drug and drug loading and to the selected release criteria. The manufacturing of the carrier can be done completely before or during loading of the drug. This renders a controlled release time to be selected from a few hours to days and months.

The drug is introduced in the carrier by mixing the drug into the precursor powder, or the hydrated $\mathrm{CBC}$ s or other porous phases. The material can be formed into a paste by mixing it with a water-based hydration liquid. The powder can also be pressed into pellets, which thereafter are soaked in the liquid. The paste or the soaked pellets start to develop the microstructure that to a great extent will contribute to the controlled release of the drug. The time and temperature after the mixing will determine the degree of hydration, i.e. the porosity obtained. The porosity can be controlled within a broad interval of open porosity.

\section{Conclusion}

The Ca-aluminate technology provides a platform upon which Ca-aluminate based materials may work as a general biomaterial and as a complement to other chemically bonded ceramics based on phosphates, silicates or sulphates. Identified areas are in the first place within the dental and orthopedic areas, where injectable stable biomaterials are required. These include also properties as bioactivity related to apatite formation, antibacterial properties as well as nanostructural features useful for carriers for controlled drug delivery. The studies presented in this paper can be summarised as follows;

- Nano-structural integration and apatite formation provide important benefits to both the dentist and patient, notably minimal micro-leakage, perfect seal at the interface between tooth and material and as a result longer-lasting treatment results.

- The potential use of the Ca-aluminate materials for implant applications is based on the following features: nanostructural integration with tissue, possible apatite formation, and a mass increase yielding early point welding between the biomaterial and surrounding.

- The following product areas have been identified based on experimental material data, pre-clinical studies, pilot studies and on-going clinical studies: dental cement, endodontic products (orthograde and retrograde), sealants, restoratives, underfillings, and pastes for augmentation and dental implant coatings.

- Consequences of nanostructural contact integration of the Ca-aluminate system are reduced risk of secondary caries and restoration failure, and reduced post-operative sensitivity.

- The Ca-aluminate material can be used as a vehicle for transport and delivery of the medicament and as an injectable implant. The combination of the material as carrier and implant material makes site-specific placement of drugs and implants possible. By introducing optional additives, or by changing the $\mathrm{w} / \mathrm{c}$ ratio, the release time can be controlled from short time periods (a few hours) to prolonged time periods (day and weeks). The release time is also dependant upon where the drug is placed. In cortical bone a release time of months seems possible. 
- The Ca-aluminate materials are not degradable and do not induce clotting or haemolysis.

- The first product in a series - a dental luting cement- was recently launched on the European and the US markets.

\section{Acknowledgment}

Results presented in this chapter are mainly based on two decades of research within Doxa $\mathrm{AB}$ and the Eng. Sci. Dept., The Angstrom Laboratory, Uppsala Univesity, Sweden.

\section{References}

Mangabhai, R. J. (1990), Calcium Aluminate Cements, Conf proceedings, Chapman and Hall Hench, L (1998) Biomaterials: a forecast for the future, Biomaterials Vol 19 1419-1423

Nilsson, M. (2003) Ph D Thesis, Injectable calcium sulphates and calcium phosphates as bone substitutes, Lund University

Scrivener, K.L.and Capmas A.; (1998) Calcium aluminate cements, In: Lea's Chemistry of Cement and Concrete, Ed. Hewett P.C., Arnold: Paris, p 709-771

Kraft, L. (2002) Ph D Thesis, Calcium aluminate based cements as dental restorative materials. Faculty of Science and technology, Uppsala University, Sweden

Loof, J; Engqvist, H.; Lindqvist, K.; Ahnfelt, N-O.; Hermansson L; (2003), Mechanical properties of a permanent dental restorative material based on calcium aluminate, Journal of Materials Science: Materials in Medicine, 14, No. 12 1033-1037

Engqvist, H.; Edlund S.; Gomez-Ortega, G.; Loof, J.; and Hermansson, L.; (2006) In vitro mechanical properties of a calcium silicate based bone void filler, Key Eng. Mater. 361-363 (369-376)

Muan, A.; Osbourne, E. A.; (1965) Phase equilibria among oxides. Adison-Wesley; New York

Lewis, G.; (2006) J. Biomed. Matls. Res. PartB: Applied Biomaterials 76B: 456-468

H. Engqvist, J. Loof, S. Uppstrom, M. W. Phaneuf, J. C. Jonsson, L. Hermansson, N-O. Ahnfelt, (2004), Transmittance of a bioceramic calcium aluminate based dental restorative material, Journal of Biomedical materials Research Part B: Applied Biomaterials vol. 69 no. 1, 94-98

Lööf, J. (2008) Ph D Thesis, Calcium-aluminate as biomaterial: Synthesis, design and evaluation. Faculty of Science and Technology, Uppsala, University, Sweden

Lööf, J.; Engqvist H.; Gómez-Ortega, G.; Spengler, H.; Ahnfelt, N-O.; Hermansson, L.; (2005) Mechanical property aspects of a biomineral based dental restorative system, Key Engineering Materials Vols. 284-286, 741-744

Loof, J.; Engqvist, H.; Hermansson, L.; Ahnfelt, N-O. (2004) Mechanical testing of chemically bonded bioactive ceramic materials, Key Engineering Materials Vols. 254-256, 51-54

Hermansson, L.; Kraft, L.; Lindqvist, K.; Ahnfelt, N-O.; Engqvist, H.; (2008) Flexural Strength Measurement of Ceramic Dental Restorative Materials, Key Engineering Materials, Vols. 361-363, 873-876

Williams, D.D.; (1987) Definitions in Biomaterials, Chaper 8, pp 66-71, Ed. Elsevier, New York

Cao, W.; Hench L.L.(1996), Bioactive materials, Ceramics International, Vol 22 493-507 ISO 10993:2003 EN 29917:1994/ISO 9917: 1991

Liu, Y.; Sahlberg, L.; Kraft, L.; Ahnfelt, N-O.; Hermansson, L.; Ekstrand, J. (2002) Aspects of Biocompatibility and Chemical Stability of Calcium-Aluminate-Hydrate Based 
Dental Restorative Material, Paper IX in Ph D Thesis by L. Kraft, Uppsala University 2002

Engqvist, H.; Lööf, J.; Kraft, L.; Hermansson, L.; (2004) Apatite formation on a biomaterialbased dental filling material, Ceramic Transactions, Vol 164 , Biomaterials: Materials and Applications, V. 2004;164:37-42.

Faris, A.; Engqvist, H.; Lööf, J.; Ottosson, M.; Hermansson, L.; (2006) In vitro bioactivity of injectable ceramic orthopaedic cements, Key Eng. Mater. 309-11, 1401-1404

Engqvist, H.; Couillard, M.; Botton, G.A.; Phaneuf, M.P.; Axén, N.; Ahnfelt, N-O. and Hermansson, L.; ( 2005), In vivo bioactivity of a novel mineral based based orthopaedic biocement, Trends in Biomaterials and Artificial Organs, 19, 27-32

Engqvist, H.; Schultz-Walz, J-E.; Lööf, J.; Bottom, G.A.; Mayer, D.; Phaneuf, M.W.; Ahnfelt, N-O.; Hermansson, L.; (2004), Biomaterials Vol 25, 2781-2787

FAO/WHO Joint Expert Committee on Food Additives (JECFA)

Jefferies, S.R.; Appleby, D.; Boston, D.; Pamiejer, C.M..; and Lööf, J.; (2009). Clinical performance of a bioactive dental luting cement- A prospective clinical pilot study. J. of Clinical Dentristy XX, No. 7, 231-237 ISO 10993-12: 1992 ISO 10993-5:1992, clause 8.4 .1

Tang, A.T.H.; Li, J.; Ekstrand, J.; and Liu, Y. (2002), Cytotoxicity tests of in situ polymerized resins: Methodological comparisons and introduction of a tissue culture insert as a testing device J Biomed Mater Res, 45, 214-222.

Schmalz, G.; Rietz, M.; Federin, M.; Hiller, H-A.; Schweikl, H.; (2002) Pulp derived cell response to an inorganic direct filling material, Abstact, presented at Cardiff Conference,

Hermansson, L.; Höglund, U.; Olaisson, E.; Thomsen, P.; Engqvist, H.; (2008) Comparative study of the bevaiour of a novel injectable bioceramic in sheep vertebrae, Trends in Biomater. Artif. Organs, Vol 22, 134-139

Axén, N.; Ahnfelt, N-O.; Persson, T.; Hermansson, L.; Sanchez, J. and Larsson, R.; (2004), A comparative evaluation of orthopaedic cements in human whole blood, Proc. 9th Ceramics: Cells and tissue, Faenza

Hermansson, L.; Lööf J. and Jarmar, T.; (2009) Integration mechanisms towards hard tissue of Ca-aluminate based materials, Key Eng. Mater. Vol 396-398, 183-186

Hermansson, L.; Engqvist, H.; Lööf, J.; Gómez-Ortega G. and Björklund, K.; (2006) Nanosize biomaterials based on Ca-aluminate Advances in Science and technology, Key Eng. Mater. Vol 49 21-26

Hermansson, L.; Lööf, J. and Jarmar, T.; (2008) Injectable ceramics as biomaterials today and tomorrow, in Proc. ICC 2, Verona 2008

Ravagliolo, A.; and Krajewski, A.; (1992) Bioceramics, Chapman and Hall, Mjör, I.; (2000) Int Dental Journal, Vol 50 [6], 50

Pameijer, C.H.; Jeffries, S.R.; Lööf, J. and Hermansson, L.; (2008) Microleakage Evaluation of XeraCem in Cemented Crowns, J Dent Res. 2008;87(B):3098.

Pameijer, C. H.; Jeffries, S.R; Lööf J. and Hermansson, L.; (2008) Physical properties of XeraCem, J Dent Res. 2008; 87(B):3100.

Pameijer, C. H.; Jeffries, S.R.; Lööf, J.; and Hermansson, L.; (2008) A comparative crown retention test using XeraCem, J Dent Res. 2008; 87 (B):3099.

Jefferies, S.R.; Pameijer, C.H.; Appleby, D.; Boston (2009), One month and six month clinical performance of XeraCem ${ }^{\circledR}$. J Dent Res. 2009;88(A):3146

Jefferies, S.R.; Pameijer, C.H.; Appleby, D.; Boston D.; Lööf, J.; Glantz, P-O.; (2009), One year clinical performance and post-opreative sensitivity of a bioactive dental luting cement, Swed. Dent. J. 2009 Vol 33 193-199 
Hermansson, L.; Faris, A.; Gomez-Ortega, G.; Abrahamsson, E:; Lööf, J.; (2010), Calcium aluminate based dental luting cement with improved properties - an overview, Advances in Bioceramics and Porous Ceramics, 34th Int Conf on Advanced Ceramics and Composites, , Ed. Wiley, Ceramic Eng. And Sci. Proc, Vol 31, p 27-38

Jefferies, SR.; Pameijer, CH.; Appleby, D.; Boston, D.; Lööf, J.; Glantz, P-O.; (2009) One year clinical performance and post-operative sensitivity of a bioactive dental luting cement - A prospective clinical study. Swed Dent J. 2009; 33:193-199.

Haumann, C.H.J. and R.M. Love, (2003) Biocompatibility of dental materials used in contemporary endodontic therapy: a review. Part 2, Root-canal-filling materials, International Endo J, 36: p. 147-160.

Niederman, R. and J.N. Theodosopoulou, Review: A systematic review of in-vivo retrograde obturation materials. Int Endo J, 2003. 36: p. 577-585.

Alamo, H.L., et al., A Comparison of MTA, Super-EBA, composite and amalgam as root-end filling materials using a bacterial microleakage model, International Endodontic Journal, 1999. 32: p. 197-203.

Kraft, L.; Saksi, M.; Hermansson, L.; Pameijer, CH.; (2009) A five-year retrospective clinical study of a calcium-aluminate in retrograde endodontics. J Dent Res. 2009; 88(A):1333.

Noort, R.v., (1994), Introduction to Dental Materials. Mosby Hentricht, R.L; (1971), An evaluation of inert and resorbable ceramics for future clinical applications, J. Biom. Res. 5(1): 25-51

Hamner, J.E., Reed, M.; and Gruelich, R.C.; Ceramic root implantation in baboons. J. Biom. Res, 19726 (4): p. 1-13.

Ellingsen, J-E.;Lyngstadaas, S.P. ; (2003), Bioimplant interface, improving biomaterials and tissue reactions, CRC Press LLC. Vercaigne S. et al, (1998) Bone healing capacity of titanium plasma-sprayed and hydroxylapatite coated oral implants, Clin. Oral Implants Res, 9, 261

Axén, N.; Engqvist, H.; Lööf, J.; Thomsen P.; and Hermansson, L.; (2005) , In vivo hydrating calcium aluminate coatings for anchoring of metal implants in bone, Key Eng. Mater. Vols. 284-286 831-834 21

Jarmar, T.; Uhlin, T.; Höglund, U.; Thomsen, P.; Hermansson, L.; and Engqvist, H.; Injectable bone cements for Vertebroplasty studied in sheep vertebrae with electron microscopy, Key Engineering Materials Vols. 361-363

Engqvist, H.; Hermansson, L.; (2006) Chemically bonded nano-size bioceramics based on Ca-aluminates and silicates, Ceramic Transactions. 2006; 172: 221-228. Ravaglioli et al, (2000), J Mater Sci Mater Med. 2000 11(12):763-7

Lasserre; and Bajpaj, (1998) Critical Reviews in Therapeutic Drug Carrier Systems, Vol 15, 1

Hermansson, L.; (2010), Chemically bonded bioceramic carrier systems for drug delivery, Advances in Bioceramics and Porous Ceramics, Ed. Wiley, 34th Int. Conference on Advanced Ceramics and Composites, Ceramic Eng. and Sci. Proc, Vol 31, p 77-88 


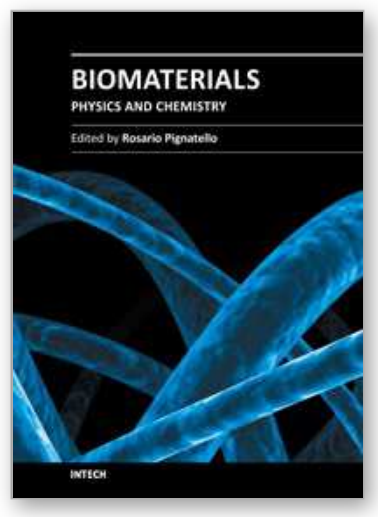

\author{
Biomaterials - Physics and Chemistry \\ Edited by Prof. Rosario Pignatello
}

ISBN 978-953-307-418-4

Hard cover, 490 pages

Publisher InTech

Published online 14, November, 2011

Published in print edition November, 2011

These contribution books collect reviews and original articles from eminent experts working in the interdisciplinary arena of biomaterial development and use. From their direct and recent experience, the readers can achieve a wide vision on the new and ongoing potentialities of different synthetic and engineered biomaterials. Contributions were selected not based on a direct market or clinical interest, but based on results coming from very fundamental studies. This too will allow to gain a more general view of what and how the various biomaterials can do and work for, along with the methodologies necessary to design, develop and characterize them, without the restrictions necessarily imposed by industrial or profit concerns. The chapters have been arranged to give readers an organized view of this research area. In particular, this book contains 25 chapters related to recent researches on new and known materials, with a particular attention to their physical, mechanical and chemical characterization, along with biocompatibility and hystopathological studies. Readers will be guided inside the range of disciplines and design methodologies used to develope biomaterials possessing the physical and biological properties needed for specific medical and clinical applications.

\title{
How to reference
}

In order to correctly reference this scholarly work, feel free to copy and paste the following:

Leif Hermansson (2011). Nanostructural Chemically Bonded Ca-Aluminate Based Bioceramics, Biomaterials Physics and Chemistry, Prof. Rosario Pignatello (Ed.), ISBN: 978-953-307-418-4, InTech, Available from: http://www.intechopen.com/books/biomaterials-physics-and-chemistry/nanostructural-chemically-bonded-caaluminate-based-bioceramics

\section{INTECH}

open science | open minds

\section{InTech Europe}

University Campus STeP Ri

Slavka Krautzeka 83/A

51000 Rijeka, Croatia

Phone: +385 (51) 770447

Fax: +385 (51) 686166

www.intechopen.com

\section{InTech China}

Unit 405, Office Block, Hotel Equatorial Shanghai

No.65, Yan An Road (West), Shanghai, 200040, China 中国上海市延安西路65号上海国际贵都大饭店办公楼 405 单元

Phone: +86-21-62489820

Fax: $+86-21-62489821$ 
(C) 2011 The Author(s). Licensee IntechOpen. This is an open access article distributed under the terms of the Creative Commons Attribution 3.0 License, which permits unrestricted use, distribution, and reproduction in any medium, provided the original work is properly cited. 